\title{
Performance Characteristics of Various Converters for Non Linear System
}

\author{
N. Padmavathi, A. Chilambuchelvan, G. Nalinashini
}

\begin{abstract}
Power Extraction from renewable energy sources plays a vital role in this century due to the depletion of non renewable energy sources, socio economic factors and expensive cost .Few examples of renewable energy sources are Solar, wind, Fuel cell and hydraulic forces. Compared to other resources solar energy leads to the best option because of the availability and less design complexity. Different converters are available for extracting the maximum power from the panel. In this paper solar panel voltage is extracted with the use of MPPT algorithm along with Boost, Buck and SEPIC converters and their performance is analyzed. Based on the performance analysis boost converter with PV panel is implemented along with MPPT algorithm. Using MATLAB Simulink 2018 environment PV panel and different types of converter are modeled and its characteristics are evaluated.
\end{abstract}

Keywords: MPPT algorithm, PV panel, SEPIC converter and MATLAB Simulink.

\section{INTRODUCTION}

Preserving Earth's energy has become an potential concern in this century because energy shortage will occur after a few decades. The interest in solar power has been fast growing due to its advantages that include: i). Explicit electric power form, ii) Less maintenance, iii). Free from pollution. Compared to other Renewable Energy Sources, Solar panels are leading in a wide range of applications, from small building incorporated systems (Roof top units) to large scale utility systems (Solar Power generation Unit) [4].

The structure of this paper is prepared as follows, in section 2, Characteristics of PV Panel, section 3 will present a summary of the used MPPT techniques. Section 4, will present the performance characteristics of the different types of converters, Maximum Power Point Tracking from Boost converter based solar panel and section 5 will combine the conclusions.

Revised Manuscript Received on November 22, 2019.

* Correspondence Author

N.Padmavathi, EIE, RMD Engineering College,Chennai,. Email:npi.eie@rmd.ac.in

G.Nalinashini, EIE, RMD Engineering College,Chennai,. Email:gns.eie@rmd.ac.in

Dr. A. Chilambuchelvan, Professor \& Head Department of EIE, RMD

Engineering College, Chennai. Email:hodeie@ @md.ac.in

\section{MODELING OF SOLAR PANEL AND MAXIMUM POWER POINT}

Solar panel consists of number of photo voltaic (PV) panels which are connected in series or parallel to extract the maximum power from sun. It is based on the photovoltaic effect through which the radiation from the Sun (photon) converted into electricity. The basic unit in the PV module is the reverse biased PN diode. One diode and two diode models are available. In order to extract the maximum power number of solar cells are connected to form a module. To produce the power in terms of MW / GW n number of PV modules is connected in parallel configuration. The output from the pv cell is directly proportional to the irradiation and temperature of the panel.

$$
I_{p h}=\left[I_{s c, n}+\alpha\left(T-T_{n}\right)\right] \frac{G}{G_{n}} \ldots \ldots \ldots(\text { eqn 1 })
$$

Where,

$\mathrm{I}_{\mathrm{ph}}-$ Current from photovoltaic cell

$I_{\mathrm{sc}, \mathrm{n}}-$ Short circuit current at the apparent condition

$\mathrm{G}$ - solar irradiance

$\mathrm{T}$ - Temperature

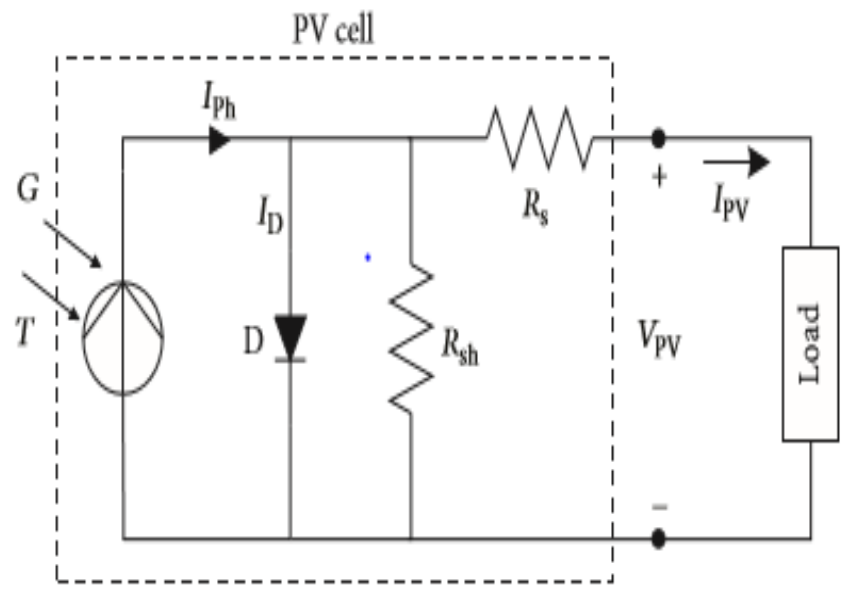

Fig 1. Single diode model of a PV cell

The single diode model of a PV cell represents the cell current given equation 2

$$
\begin{gathered}
I_{P V}= \\
I_{p h}-I_{0}\left(e^{\left(q\left(V+I \cdot R_{S}\right) /\left(n \cdot K_{B} \cdot T\right)\right)}-1\right)-\frac{V+I \cdot R_{S}}{R_{s h}} \ldots \ldots \ldots(\text { eqn } 2)
\end{gathered}
$$




\section{Performance Characteristics of Various Converters for Non Linear System}

$\mathrm{I}_{\mathrm{pv}}-$ cell output current $(\mathrm{A})$

$\mathrm{I}_{\mathrm{ph}}-$ Current from photovoltaic cell

$\mathrm{I}_{\mathrm{o}}-$ dark current

$\mathrm{V}$ - Cell output voltage

$\mathrm{q}$ - electronic charge

$\mathrm{K}_{\mathrm{B}}-$ Boltzmann's constant

n- Ideality factor

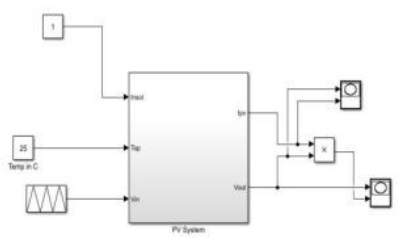

Fig. 2 Simulation model of PV Panel

Figure 3 and 4 represents the characteristics of the PV panel with different temperature and radiation. From the figure 3 and 4 we inferred that the Voltage and power is zero at the maximum short circuit current. On the other hand the solar cell can distribute the maximum power for a particular radiation and temperature and it is known as the maximum power point (MPP). From the eqns.1 and 2, output current is to be non linear and susceptible on the emission and temperature. These equations are also used to calculate the current and voltage values of the panel in MPPT algorithm.

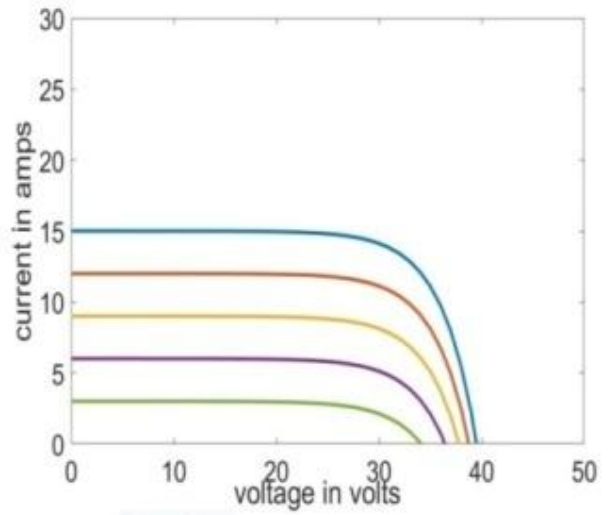

Fig. 3 I-V Characteristics of PV Panel

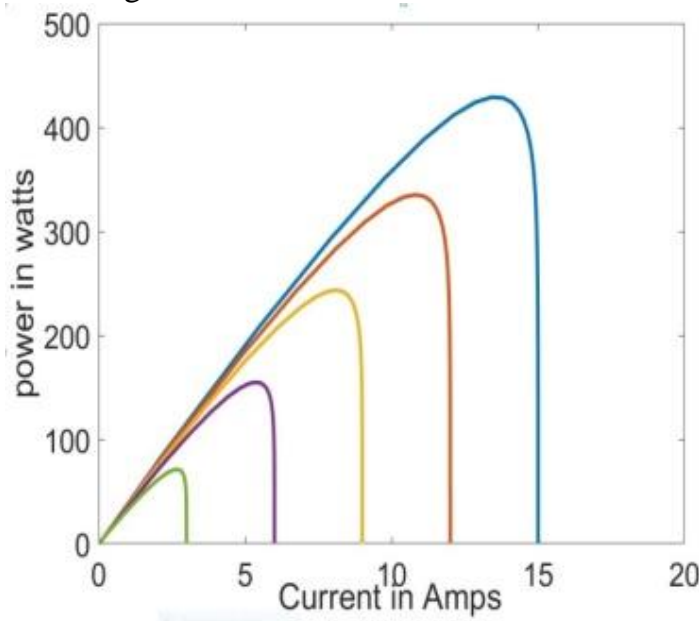

Fig. 3 P-V Characteristics of Solar Panel
Constant voltage method, short circuit current method, and as well, intelligent computing method. The above mentioned MPPT methods can dominance the PV panel's voltage or current to trail and maintain the MPP of the PV panel to increase the PV panel efficiency. Recently more converters are utilized for that purpose along with different types of MPPT algorithm.

\section{MPPT ALGORITHM}

\section{A. Perturb \& observe algorithm}

The most commonly used MPPT algorithm is $\mathrm{P} \& \mathrm{O}$ method in which it uses simple feedback arrangement and little measured parameters. In this algorithm, the panel voltage is regularly given a perturbation and the corresponding. Solar energy is the most potential candidate of green energy. Due to non linearity in PV panel characteristics is maximum power varies with partial shading effect, temperature and irradiation. The efficiency of the PV Panel is mainly based on the determination of maximum power point (MPP) irrespective of the size and type of the panel [4]. To eliminate this drawback Maximum Power Point Tracking (MPPT) techniques were used. The following methods are proposed such as hill climbing method, perturb and observe (P\&O) method, incremental conduction method. Output power is compared with that at the previous perturbing cycle. A small perturbation is introduced into the Incremental conductance system. The power of the solar module varies with respect to the perturbation [5]. The amount of perturbation is linearly proportional to the power till the MPP. Once the MPP is reached perturbation reverses as shown in Figure 4.

\section{CHARACTERISTICS OF DIFFERENT CONVERTERS}

In order to enhance the ratio between output power and installation cost, dc/dc converters are used to draw maximum power from the PV panel array [9], [10].

Types of DC - DC converters used in PV panel

i). Boost converter

ii). Buck converter

iii). Buck - Boost Converter

iv). SEPIC Converter

\section{B. Characteristics of Boost converter}

Boost converter is used to increase the input voltage to the necessary level.

The basic concept is that the duty cycle variation of the boost converter is carried out through the pulse width modulation (PWM) circuit. Modeling of the boost converter is as follows 


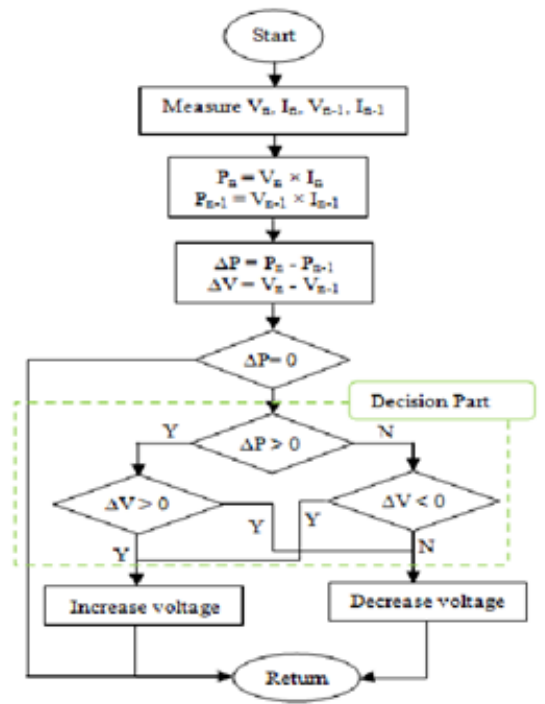

Fig 4. P\&O algorithm flow chart

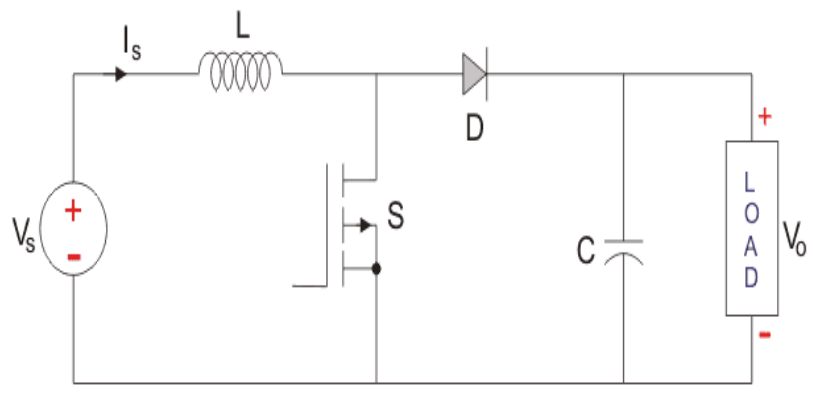

Fig 5. Boost Converter

Where,

$$
\begin{aligned}
& f_{s}=1 / T \\
& \mathrm{~T}=\mathrm{T}_{\mathrm{on}}+\mathrm{T}_{\text {off }}
\end{aligned}
$$

$\mathrm{f}_{\mathrm{s}-}$ Switching frequency

$\mathrm{T}$ - Time period

When the switch is closed,

The Inductor current is continuous by the proper selection of value of $\mathrm{L}$. Inductor current varies from the positive value to peak during the $\mathrm{ON}$ state and drops down to zero during the off condition. So the net change of inductor current over the complete cycle is zero.

\section{Buck - Boost Converter}

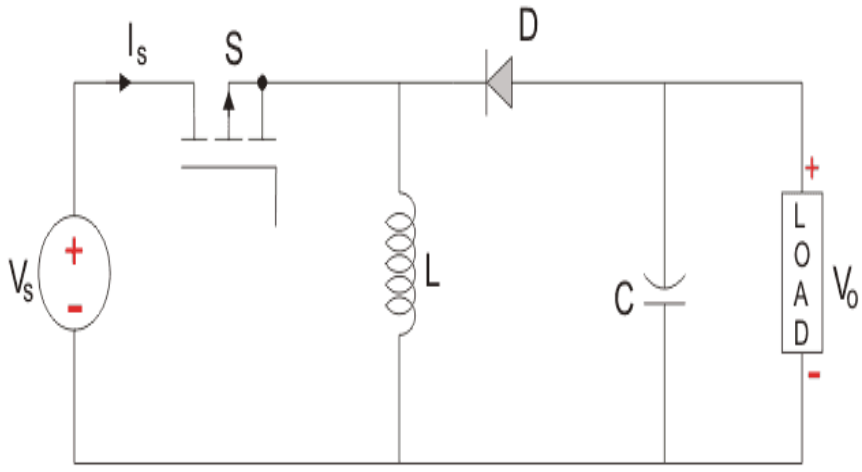

Fig 5. Buck - Boost Converter
Buck boost converter is another type of DC converter used to step down or step up the input voltage according the set point. Here the duty cycle variation is used for the same. The output voltage is characteristically of the same polarity of the input, it can be lower or higher than the input. The output voltage is variable based on the duty cycle of the switching transistor.

$$
D=\frac{V_{o}}{V_{o}-V_{i}} \quad f_{\text {switching }}=\frac{1}{T}
$$

- $\mathrm{V}_{\mathrm{O}=\text { output voltage }}$

- $\mathrm{V}_{\mathrm{i}=\text { output voltage }}$

- $\mathrm{D}=$ Duty ratio

\section{SEPIC Converter}

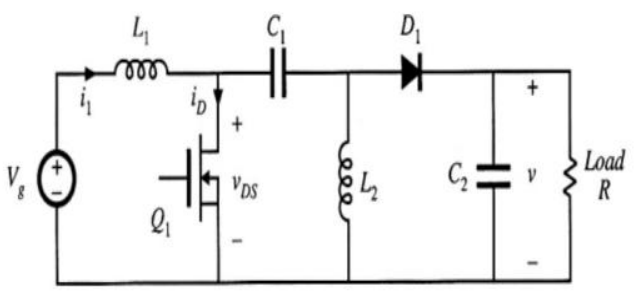

Fig. 6. SEPIC Converter

It is similar to boost converter but it provides the output voltage same as in the polarity of the input voltage. This feature is not present in the Buck - Boost converter. SEPICs are appropriate in requests in which a battery voltage can be above and below that of the regulator's planned output.

\section{RESULTS AND DISCUSSION}

The converters with the following specifications MOSFET, Inductor value $\mathrm{L}=200 \mathrm{e}^{-6} \mathrm{H}$, and Capacitor value $\mathrm{C}=220 \mathrm{e}^{-6} \mathrm{~F}$ are modeled in a MATLAB R2018a version. The readings are tabulated and from the fig.7 it has been observed the Boost converter performance is superior than the other converters in terms of its voltage conversion efficiency. Even though the boost converter has the limitation of high voltage ripples it is mainly recommended for solar power extraction. It is also observed that SEPIC converter performance is better than Buck boost and does not need any conversion unit for output voltage polarity change. 
Performance Characteristics of Various Converters for Non Linear System

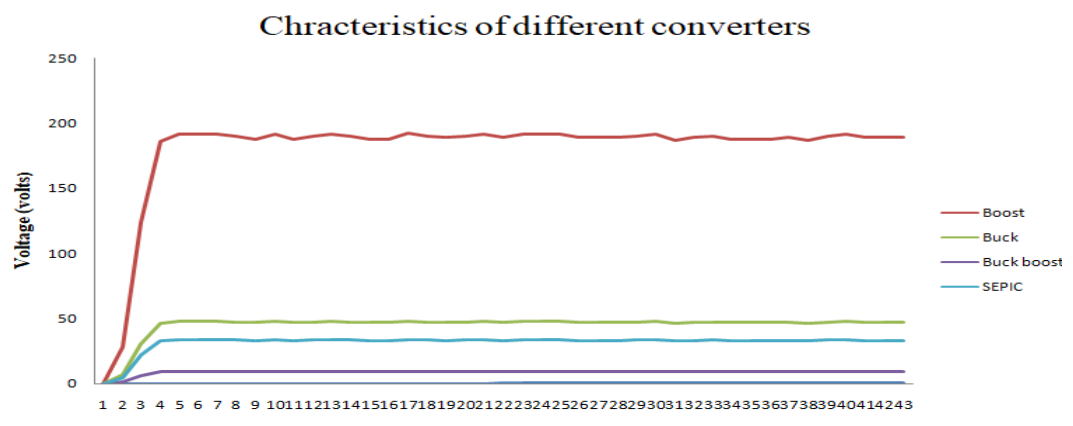

Fig 7. Output characteristics of the Boost, Buck, Buck - boost and SEPIC converter

Based on the discussion from the fig. 7 and Table 1 the next section proposed the PV Panel along with Boost converter and the maximum power point is extracted using $\mathrm{P} \& \mathrm{O}$ algorithm.

\begin{tabular}{|c|c|c|c|c|}
\hline \multirow{2}{*}{$\begin{array}{l}\text { Time } \\
\text { secs }\end{array}$} & \multicolumn{4}{|c|}{ Voltage in volts } \\
\hline & Boost & Buck & Buck Boost & SEPIC \\
\hline 0 & 0 & 0 & 0 & 0 \\
\hline 0 & 28.385 & 7.09625 & 1.29022727 & 4.979824561 \\
\hline 0.005 & 123.872 & 30.968 & 5.63054546 & 21.73192982 \\
\hline 0.008 & 185.72 & 46.43 & 8.44181818 & 32.58245614 \\
\hline 0.012 & 191.146 & 47.7865 & 8.68845455 & 33.53438596 \\
\hline 0.015 & 191.146 & 47.7865 & 8.68845455 & 33.53438596 \\
\hline 0.018 & 191.146 & 47.7865 & 8.68845455 & 33.53438596 \\
\hline 0.021 & 190.061 & 47.51525 & 8.63913636 & 33.34403509 \\
\hline 0.024 & 187.891 & 46.97275 & 8.5405 & 32.96333333 \\
\hline 0.026 & 191.146 & 47.7865 & 8.68845455 & 33.53438596 \\
\hline 0.03 & 187.891 & 46.97275 & 8.5405 & 32.96333333 \\
\hline 0.032 & 190.061 & 47.51525 & 8.63913636 & 33.34403509 \\
\hline 0.036 & 191.146 & 47.7865 & 8.68845455 & 33.53438596 \\
\hline 0.039 & 190.061 & 47.51525 & 8.63913636 & 33.34403509 \\
\hline 0.042 & 187.891 & 46.97275 & 8.5405 & 32.96333333 \\
\hline 0.044 & 187.891 & 46.97275 & 8.5405 & 32.96333333 \\
\hline 0.047 & 192.231 & 48.05775 & 8.73777273 & 33.72473684 \\
\hline 0.05 & 190.061 & 47.51525 & 8.63913636 & 33.34403509 \\
\hline 0.053 & 188.976 & 47.7865 & 8.58981818 & 33.15368421 \\
\hline 0.056 & 190.061 & 47.7865 & 8.63913636 & 33.34403509 \\
\hline 0.059 & 191.146 & 47.244 & 8.68845455 & 33.53438596 \\
\hline 0.061 & 188.976 & 47.244 & 8.58981818 & 33.15368421 \\
\hline 0.065 & 191.146 & 47.244 & 8.68845455 & 33.53438596 \\
\hline 0.067 & 191.146 & 47.7865 & 8.68845455 & 33.53438596 \\
\hline 0.07 & 191.146 & 47.7865 & 8.68845455 & 33.53438596 \\
\hline 0.073 & 188.976 & 47.244 & 8.58981818 & 33.15368421 \\
\hline 0.076 & 188.976 & 47.244 & 8.58981818 & 33.15368421 \\
\hline 0.079 & 188.976 & 47.244 & 8.58981818 & 33.15368421 \\
\hline 0.082 & 190.061 & 47.244 & 8.58981818 & 33.34403509 \\
\hline
\end{tabular}

Table .1 Quantitative Analysis of Boost, Buck, Buck - Boost and SEPIC Converters

\section{PERFORMANCE EVALUATION OF PV PANEL WITH BOOST CONVERTER}




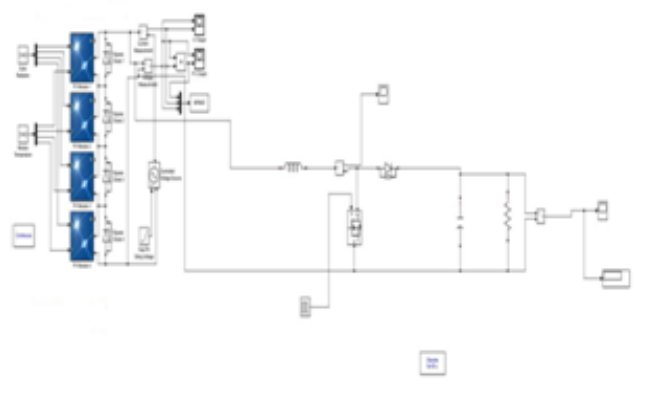

Fig 8. Simulation Diagram of PV Panel

The PV Panel with the following specification simulated in MATLAB environment in Intel i7 processor

\begin{tabular}{|l|l|}
\hline Parameters & Values \\
\hline Voc - Open circuit & 23.5 \\
Isc - short circuit & 5.6 \\
V - Voltage & 16.7 \\
Current - I & 3.45 \\
Power max(maximum) - Pm & 68.9 \\
& \\
Quality factor - A & 1.2 \\
\hline
\end{tabular}

Table 1 Data inputs for simulation - PV module ISOFOTON I-75The boost converter is connected along with solar panel and the duty cycle of the boost converter is varied based on $\mathrm{P} \& \mathrm{O}$ algorithm through the PWM controller. Fig.8 represents the simulation diagram of the PV panel.

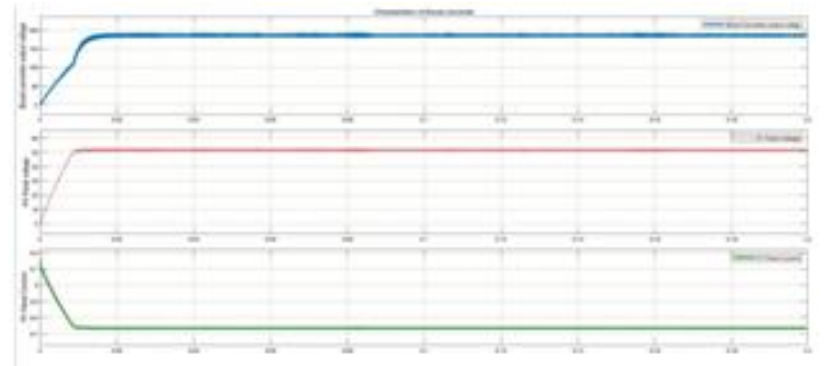

Fig 9. PV Voltage, Current and Boost converter output waveforms

From the Fig 9 PV panel output voltage is increased from 50 volts to 180 volts by the implementation of Boost converter along with MPPT algorithm. Implementation of Boost converter is very simple compared to other types. It is very useful to extract the power from the panel under the Partial shaded condition also.

\section{REFERENCES}

[1] E. Koutroulis, K. Kalaitzakis, and N. C. Voulgaris, "Development of a microcontroller-based, photovoltaic maximum power point tracking control system," IEEE Trans. Power Electron., vol. 16, no. 21, pp. 46-54, Jan. 2001.

[2] M.Veerachary,T.Senjyu,andK.Uezato,"Maximum power point tracking control of IDB converter supplied PVsystem,"inProc.IEEE Proc.Elect. Power Appl., 2001, pp. 494-502.
[3] A. Pandey, N. Dasgupta, and A. K. Mukerjee, "High-performance algorithms for drift avoidanc eandfasttrackinginsolarMPPTsystem," IEEE Trans. Energy Convers., vol. 23, no. 2, pp. 681-689, Jun. 2008.

[4]. Random Forest-Based Approach for Maximum Power Point Tracking of Photovoltaic Systems Operating under Actual Environmental Conditions, HussainShareef,1 AmmarHusseinMutlag,2 andAzahMohamed3, Hindawi Computational Intelligence and Neuroscience, June 2017.

[5] N. Femia, G. Petrone, G. Spagnuolo, and M. Vitelli, "Optimization of perturb band observe maximum power point tracking method," IEEETrans. Power Electron., vol. 20, no. 4, pp. 963-973, Jul. 2005.

[6] J. Sachin and V. Agarwal, "An integrated hybrid power supply for distributed generation applications fed by nonconventional energy sources," IEEE Trans. Energy Convers., vol. 23, no. 2, pp. 622-631, Jun. 2008.

[7]. Ahmed M. Atallah, Almoataz Y. Abdelaziz, and Raihan S. Jumaah "Implementation Ofperturband Observe MPPT of PVSystem With Direct Control Method Using Buck And Buck Boost Converters", Emerging Trends in Electrical, Electronics \& Instrumentation Engineering: An international Journal (EEIEJ), Vol. 1, No. 1, February 2014.

[8] A. F. Boehringer, "Self-adapting dc converter for solar spacecraft power supply," IEEE Trans. Aerosp. Electron. Syst.,vol.AES4,no.1,pp.102-111, Jan. 1968.

[9] B. Subudhi and R. Pradhan, "A Comparative Study on Maximum Power Point Tracking Techniques for Photovoltaic Power Systems", IEEE Trans. Sustain. Energy, vol. 4, no. 1, pp. 89-98, 2013.

[10] M. A. Elgendy, B. Zahawi, and D. J. Atkinson, Assessment of the incremental conductance maximum power point tracking algorithm," IEEE Trans. Sustain. Energy, vol. 4, no. 1, pp. 108-117, Jan. 2013.

\section{AUTHORS PROFILE}

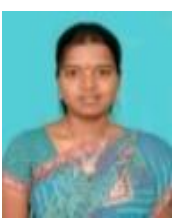

Mrs. N. PADMAVATHI is working as assistant professor in the department of EIE at R.M.D Engineering College. Her areas of interest are Renewable Energy Systems, Converters in Solar Panels, soft computing. She has presented 05 papers in International Conferences and published Two papers in International journals.

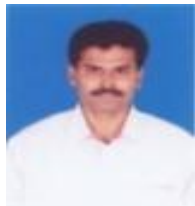

Dr. A. ChILAMbUChelVAN is working as Professor \& Head in the department of EIE at R.M.D Engineering College. His reas of interest are embedded system, VLSI design, soft computing. He has published 46 papers in International journals.

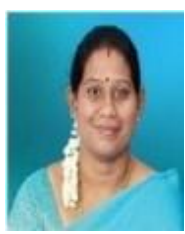

Dr. G. Nalinashini working as associate professor in the department of EIE at RMD Engineering College obtained her $\mathrm{PhD}$ (Electrical Engineering) from Anna University, Chennai in the year 2014. Her areas of interest include Electrical Engineering, Special Electrical machines, Artificial Intelligence, Biomedical Instrumentation, Programmable Logic Controllers. She has published 12 papers in various International Journals and Conferences. 